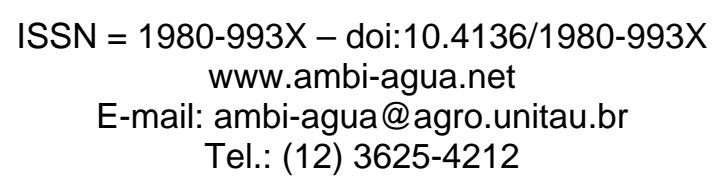

\title{
Municipal waste management and groundwater contamination processes in Córdoba Province, Argentina (doi:10.4136/ambi-agua.152)
}

\author{
María Laura Gomez*1; Daniel Emilio Martínez*2 \\ *CONICET Consejo Nacional de Investigaciones Científicas y Técnicas \\ ${ }^{1}$ Instituto Argentino de Nivología, Glaciología y Ciencias Ambientales (IANIGLA) \\ CCT- Mendoza. Av. Ruíz Leal s/n, Parque Gral. San Martín. Mendoza. Argentina. CP 5500 \\ E-mail: lgomezcba@gmail.com \\ ${ }^{2}$ Instituto de Geología de Costas y el Cuaternario, Universidad Nacional de Mar del Plata \\ Diagonal J. B. Alberdi 2695 - Mar del Plata. Buenos Aires. Argentina. CP. 7600 \\ E-mail: demarti@mdp.edu.ar
}

\begin{abstract}
In Coronel Moldes, Argentina, waste management practices consist in municipal waste being tipped directly onto an area of sand dunes at the municipal waste disposal site (MWDS). Moreover, untreated liquid waste from septic tanks and latrines from urban areas are discharged in the same place. This co-disposal waste management is very common in many regions of Argentina and its impact on the groundwater of Coronel Moldes has not been evaluated. The study area is located in the vicinity of a MWDS in a flatlands environment that is typical of Argentina. The main objective of this study was to evaluate the impacts on groundwater quality of current waste management practices in order to consider the requirement for new guidelines for sustainable groundwater management. Three groundwater monitoring wells were installed up-, across- and down-gradient of the MWDS. The principal aquifer is formed by sandy silt sediments (loess). Groundwater levels in the area of the MWDS are between $5.6 \mathrm{~m}$ and $7.8 \mathrm{~m}$. The Vulnerability index indicates that groundwater in this area has a high vulnerability. Groundwater in the vicinity of the MWDS shows elevated electrical conductivity, high concentrations of $\mathrm{Cl}^{-}, \mathrm{Na}^{+}$, and $\mathrm{HCO}_{3}^{-}$ions, $\mathrm{COD}, \mathrm{BOD}_{5}$ and aerobic bacteria and less dissolved oxygen than the background values indicating the presence of organic matter. Municipal waste management represents a significant omission in current groundwater protection policy at Coronel Moldes. Strict supervision of solid and liquid municipal waste disposal needs to be instigated in order to ensure that the groundwater remains free of contamination and to allow a sustainable environmental management.
\end{abstract}

Keywords: Waste management; groundwater; loess aquifer; contamination; Pampa Argentina.

\section{Gestão de resíduos urbanos e os processos de contaminação das águas subterrâneas na Província de Córdoba, Argentina}

\section{RESUMO}

Em Coronel Moldes, Argentina, práticas de gestão de resíduos envolvem o lançamento de resíduos sólidos urbanos diretamente sobre uma área de dunas de areia no local de disposição de resíduos municipais (MWDS). Além disso, os resíduos líquidos não tratados provenientes de fossas sépticas e latrinas em áreas urbanas são descarregadas no mesmo lugar. Esta co-disposição de resíduos é muito comum em muitas regiões da Argentina e seu impacto sobre as águas subterrâneas de Coronel Moldes não havia sido avaliado. A área de estudo está localizada nas proximidades de um MWDS em um ambiente de planícies típico da Argentina. O principal objetivo deste estudo foi avaliar os impactos das práticas de gestão dos resíduos sobre a qualidade das águas subterrâneas para subsidiar novas diretrizes para a 
gestão sustentável das águas subterrâneas. Três poços de monitoramento do lençol freático foram instalados nos gradientes superior, transversal e inferior do MWDS. O aquífero principal é formado por sedimentos silto-arenosos (loess). Os níveis das águas subterrâneas na área do MWDS estão entre 5,6 m e 7,8 m. O índice de vulnerabilidade indica que as águas subterrâneas nessa área têm uma elevada vulnerabilidade. As águas subterrâneas nas proximidades do MWDS apresentaram elevada condutividade elétrica, altas concentrações de $\mathrm{Cl}^{-}, \mathrm{Na}^{+}$e $\mathrm{HCO}_{3}-$, DQO, $\mathrm{DBO}_{5}$ e de bactérias aeróbias e menos oxigênio dissolvido do que os valores de base indicando a presença de matéria orgânica. A gestão de resíduos urbanos em Coronel Moldes apresenta uma lacuna significativa na atual política de proteção das águas subterrâneas. Há a necessidade de supervisão atenta do tratamento de resíduos líquidos e sólidos municipais a fim de assegurar que as águas subterrâneas permaneçam livres de contaminação e permitir uma gestão ambiental sustentável.

Palavras-chave: gestão de resíduos; águas subterrâneas; aquífero Loess; contaminação; Pampa Argentino.

\section{INTRODUCTION}

Groundwater constitutes $97 \%$ of the planet's freshwater resources available for human use (Zaporozec, 2002). It has an important role, and is a vital source of drinking water in many urban and rural areas of Latin America and the Caribbean (Foster and Hirata, 1988). Human activities produce waste that, in some cases, may threaten groundwater reserves. During the last few decades, urbanization has taken on an alarming expansion. Urban areas have increased considerably and facilities for the disposal of waste have not always been implemented in a satisfactory manner to keep up with this expansion (Zaporozec, 2002). Although in developing countries, the quantity of solid waste generated in urban areas is low compared to industrialized countries, municipal solid waste management still remains inadequate (Henry et al., 2006).

The presence of reactive material concentrated in a relatively small area produces a localized geochemical environment at waste management sites that may produce a contaminant plume (Deutsch, 1997). Dumping sites for municipal waste often produce a leachate that migrates to adjacent areas, resulting in gross pollution of soil, surface water and groundwater. The leachate may contain matter that is resistant to biological or chemical changes, and that therefore remains in the soil for many years (Bocanegra et al., 2001).

In Argentina, one of the most significant environmental problems is the final placement of municipal solid waste disposal. In many regions, the waste is tipped over land, which can result in significant impacts to both the local environment and human health. Municipal waste disposal sites (MWDS) are the most common forms of waste management facility in Argentina, especially in Córdoba Province. Only 7.5\% of the municipal waste in Argentina is disposed of to landfill (Nirich, 2000).

Groundwater in Coronel Moldes, located on the Chacopampeanan Plain of Central Argentina, represents the only source of drinking, agricultural and industrial water available. The city has a population of over 9,000 inhabitants. The municipal waste disposal site in Coronel Moldes represents a significant threat to the quality of unconfined groundwater in the area. The MWDS at Coronel Moldes is a typical example of an uncontrolled municipal solid and liquid wastes handling facility with no controlled disposal, containment system or treatment facility. The site is located $5 \mathrm{Km}$ to the East of Coronel Moldes, in Cordoba Province, Argentina (Figure 1), where waste is dumped without any treatement or protective action. Waste is tipped directly over land with no pre-treatment. Moreover, untreated liquid waste from septic tanks and latrines from urban areas are discharged daily onto the disposal site again with no sanitary precautions. Both solid and liquid wastes have been disposed of in 
this way since 1982. It is clear that the MWDS and liquid waste from an on-site-sanitation system (LWOSS) threaten the quality of the local groundwater.

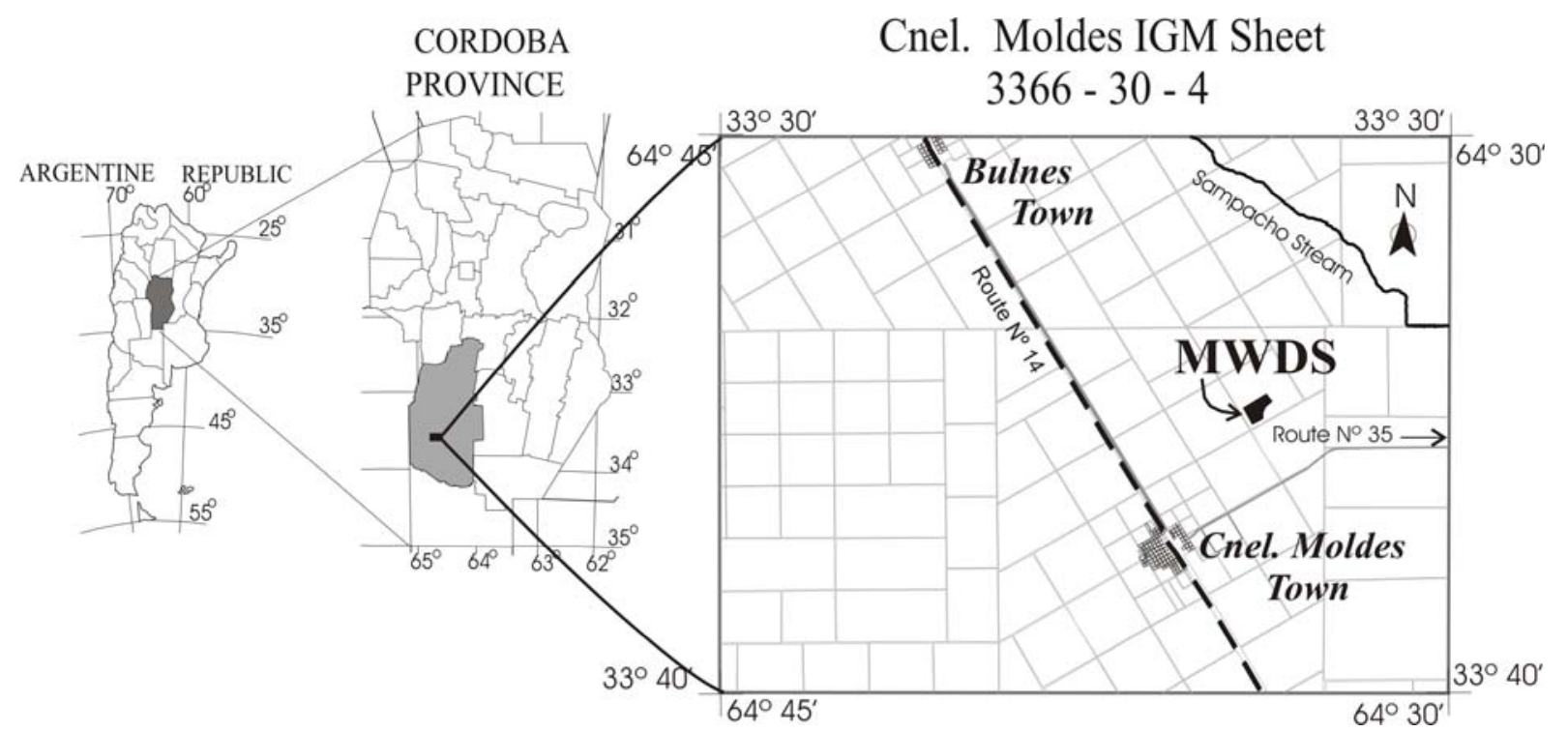

Figure 1. Location of Coronel Moldes Municipal Waste disposal site.

Waste management in Coronel Moldes has a serious lack of public and environmental awareness and its impact on groundwater has not been evaluated. The objective of this study is to determine the impact that uncontrolled municipal liquid and solid waste disposal may have on groundwater in Coronel Moldes. The study looks at groundwater impacts both on the local loess aquifer, which is typical of many groundwater settings on the Argentinean Chacopampeanan Plain, and a nearby area of sand dunes. In particular the study looks at groundwater characterization and assessment of the vulnerability of particular groundwater types to contamination. This characterization is the basis for the production of a groundwater vulnerability map, and the consequent classification of geographical locations with different susceptibilities to groundwater pollution. Vulnerability mapping is a useful decision-making tool to be considered in land use planning as well as in water resource management programs worldwide (Nobre et al., 2007). Vulnerability information, added to hydrogeochemical studies, will allow a better characterization of the groundwater system and the possibility of more intelligent land-use planning, especially in areas located in the vicinity of a municipal waste disposal site.

The study includes hydrological and hydrogeochemical analysis and interpretation of the loess aquifer under the disposal site as well as determination of the level of groundwater pollution and the chemical characteristics of LWOSS. The understanding of its hydrological characteristics and hydrogeochemical processes is the starting point for the development of improved management practices, groundwater protection policies and a sustainable development framework for groundwater resources. The determination of the extent of groundwater contamination from solid and liquid municipal wastes gives important information that may help local authorities to strategically locate future waste disposal sites as well as to define more effective environmental protection strategies.

\section{METHODOLOGY}

The study area covers an area of approximately $440 \mathrm{Km}^{2}$. However, a more detailed survey of a smaller 11Ha area surrounding the disposal site was also carried (Figure 2). A geological and geomorphological study was carried out of both study areas using Landsat ETM + 229/83 satellite images, for large scale study, and topographic sheets from IGM (Instituto Geográfico Militar) for local study. Outcropping geological units were mapped in 
the field and the geological logs of the study aquifer were supplied by DIPAS (DIPAS, 1999). These comprised two deep boreholes to $200 \mathrm{~m}$ depth in Coronel Moldes and Bulnes town, including 3 shallow boreholes in the immediate vicinity of the MWDS area. Sediment samples were collected from selected lithologies during well drilling, including sand dunes, natural soil, and soil under MWDS.

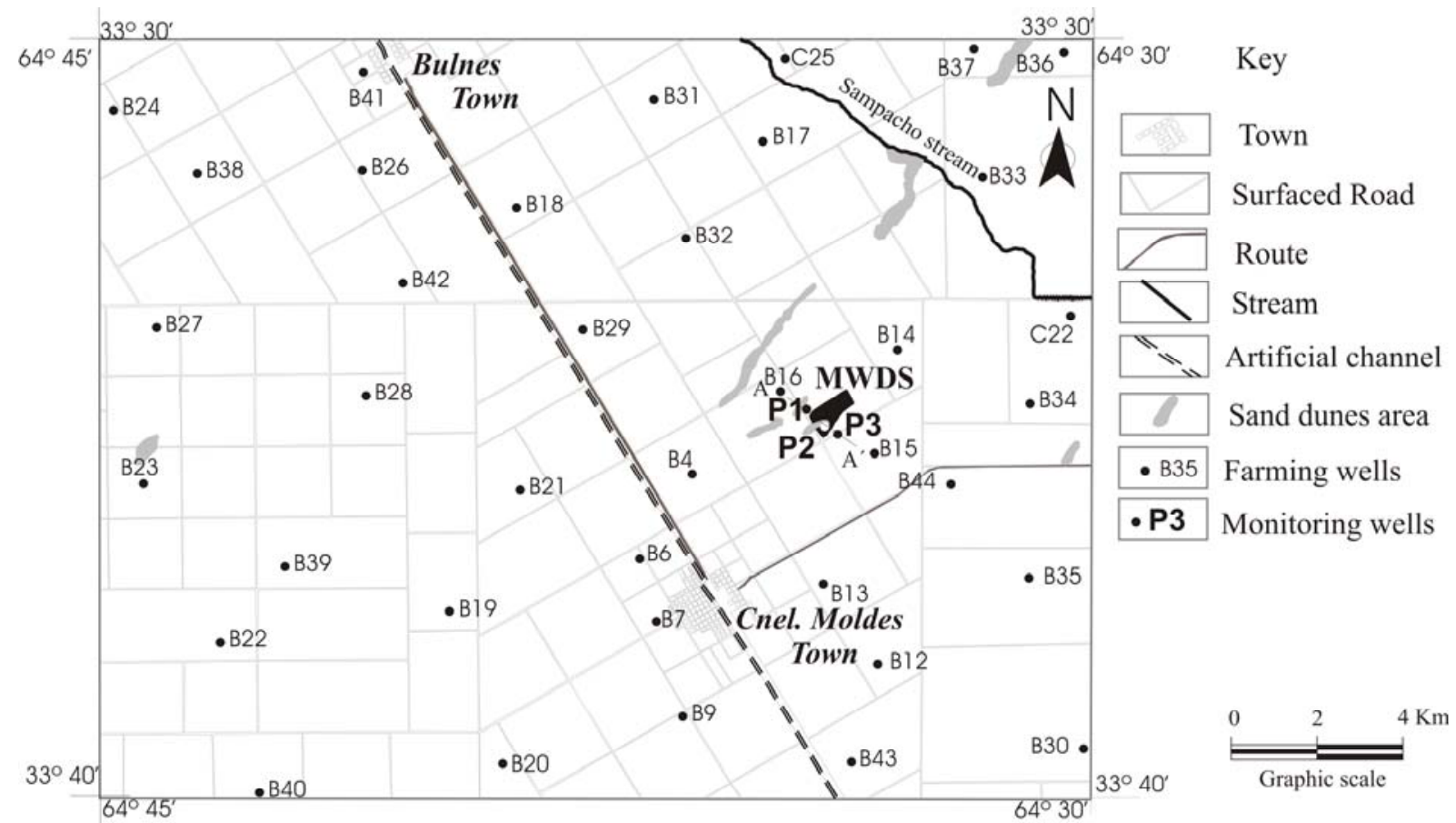

Figure 2. Study area and location of wells (38 samples from farming wells in Coronel Moldes unconfined aquifer) and MWDS with the location of monitoring wells. A-A indicates the cross section position of Figure 3.

Four samples from the LWOSS pond were collected monthly from February to June in 2007.

To assess the quality of groundwater in the vicinity of the MWDS, 38 samples were taken in the unconfined aquifer from February to June in 2007, all of these samples correspond to rural hand-dug wells with less than $20 \mathrm{~m}$ depth. Three wells were drilled on the disposal site area along an identified groundwater flow path in order to better understand of the evolution of groundwater quality from upstream to downstream of the facility. The first piezometer (P1) was located upgradient of the MWDS (in a local recharge area), the second (P2) over the MWDS and immediately downgradient of LWOSS, and the third piezometer (P3) $30 \mathrm{~m}$ downgradient of the MWDS (Figure 3). Each piezometer was installed with a $3 \mathrm{~m}$ slotted section (open to groundwater) attached to a section of plain (unslotted) pipe. The depth-to-open interval of the piezometers ranges from about 6 to $14 \mathrm{~m}$.

Temperature, electrical conductivity (EC) and $\mathrm{pH}$ were measured in the field using handheld instruments. Also, dissolved oxygen (DO) was measured with a polarographic sensor in the LWOSS pond and piezometers P2 and P3. Background values of aquifer dissolved oxygen were taken from studies by Blarasín (2003). Phreatic aquifer levels were measured in piezometers and wells using a dipmeter.

Samples were taken and transferred immediately to properly preserved containers and placed on ice for transportation to the laboratory. Samples were collected in $1 \mathrm{~L}$ plastic bottles and were analyzed immediately in order to avoid changes in geochemistry between the field and the laboratory. When this was not possible, they were preserved refrigeratedat below $5^{\circ} \mathrm{C}$ in coolboxes until analysis was performed. An acidified aliquot $\left(\mathrm{H}_{2} \mathrm{SO}_{4}\right)$ was taken for COD analysis according to APHA et al. (1995) standard methods. 


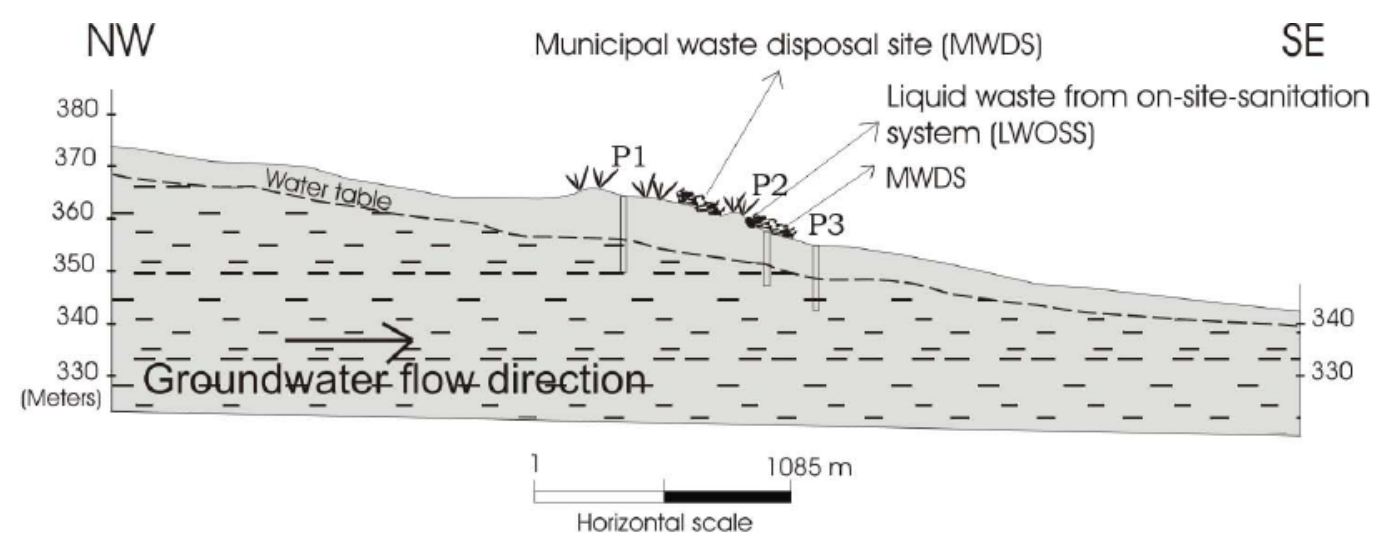

Figure 3. West - East hydrogeological cross-section through the MWDS along the line A-A shown in Figure 2. P1, P2 and P3 are wells drilled on the disposal site area over a line flow.

The parameters measured were $\mathrm{pH}$ (Electrode Oryon 9104 and potentiometer $710 \mathrm{~A}$ ), conductivity (Hanna Instrument $\mathrm{HI} 9033$ ) $\mathrm{Na}^{+}, \mathrm{K}^{+}$(flame photometric method), $\mathrm{HCO}_{3}{ }^{-}, \mathrm{Cl}^{-}$, $\mathrm{Mg}^{+2}, \mathrm{Ca}^{+2}, \mathrm{SO}_{4}^{-2}, \mathrm{SiO}_{2}$ (APHA et al., 1995), $\mathrm{F}^{-}, \mathrm{NO}_{3}{ }^{-}$(Ion-Selective Fluoride and Nitrate Electrode, Orion Models 9609 and 9307) and $\mathrm{As}_{\text {(Total) }}$ (Atomic absorption spectrophotometer Analyst 300 Perkin-Elmer). Chemical and Biochemical Oxygen Demand (COD-BOD 5 ) was measured in the same samples (APHA et al, 1995) together with bacteriological analysis in the National University of Río Cuarto.

For the evaluation of groundwater vulnerability the DRASTIC method (Aller et al., 1987) was applied using ArcView GIS (ESRI, 1999). DRASTIC categorizes aquifer vulnerability to contamination from surface sources according to seven criteria. The analytical steps mainly involved simple map operations within ArcView Spatial Analyst (ESRI, 1999).

\section{RESULTS AND DISCUSSION}

\subsection{Site description and installation of piezometers}

The municipal waste disposal site has accumulated rubbish produced from Coronel Moldes since 1982. Nearly 84 tons of solid wastes are deposited onto the site, which is located on an area of sand dunes, every day. Solid wastes are placed directly over the natural soil without any control or management. The MWDS is located at $360 \mathrm{~m}$ above sea level, in flatlands that have a local topographic gradient of $1.3 \%$ (in the sands dunes area) over an average of $0.55 \%$ out of a total area of $440 \mathrm{Km}^{2}$. The waste handled by the MWDS comes mainly from domestic solid waste. Field investigations confirm that most of the waste is of urban origin and includes organic matter and plastic with lesser amounts of metals, glass, pneumatic and textile. Also bags of salt $(\mathrm{NaCl})$ used in tanneries and slaughterhouses, cans of pesticides and fertilizers, and organic matter from slaughterhouses, are commonly found.

\subsection{Quality of leachate}

Leachate from the LWOSS showed an electrical conductivity ranging from 2,500 to $4,000 \mu \mathrm{S} / \mathrm{cm}$ in samples taken between February to June in 2007. Sodium, chloride and bicarbonate are the principal ions present with concentrations of over $450 \mathrm{mg} / \mathrm{L}, 1,200 \mathrm{mg} / \mathrm{L}$ and $1,000 \mathrm{mg} / \mathrm{L}$ respectively. The $\mathrm{pH}$ value of the leachate was around 8 . DO measured in March 2007 was $0.77 \mathrm{mg} / \mathrm{L}$. Ammonium, measured was $1.6 \mathrm{mg} / \mathrm{L}$ and the only nitrogen species detected. High values of COD $(614.8 \mathrm{mg} / \mathrm{L})$ and $\mathrm{BOD}_{5}(100 \mathrm{mg} / \mathrm{L})$ were found, suggesting an organic origin. In general, the laboratory result indicates reducing conditions for leachate. Bacteriological analysis showed very high values for aerobic bacteria, total coliforms and faecal coliforms (pseudomonas aeruginosa) (Table 1). 
Table 1. Bacteriological analysis in the leachate of the LWOSS measured in March 2007.

\begin{tabular}{c|c}
\hline \multicolumn{2}{c}{ Bacteriological analysis } \\
\hline Coliforms organisms & Escherichia coli \\
{$[\mathrm{NMP} / 100 \mathrm{ml}]$} & {$[\mathrm{NMP} / 100 \mathrm{ml}]$} \\
$210^{10}$ & Fecal Coliforms $<3$ \\
\hline
\end{tabular}

\subsection{Hydrogeological and Hydrodynamics Setting}

The sediments in the study area correspond to aeolian Quaternary materials. The aquifer is comprised of the Laguna Oscura and Pampiano Formation from the Middle and Upper Pleistocene. The phreatic aquifer consists of around $50 \mathrm{~m}$ of unconsolidated fine sands and silts of aeolian origin known as loess. Thin layers of calcrete are interbedded with the sediments. These sediments dominate the lithological sequence found in the Coronel Moldes area (Figure 4).

The Quaternary silty-sand unconfined aquifer is being exploited by rural areas as the only water supply resource. The confined aquifer exploited in Coronel Moldes city is between 154-161 m deep.

The vicinity of the MWDS area belongs to the typical loess plain of the south of Cordoba province described by Cantú and Degiovanni (1987). According to these authors, the loess sediments were locally remobilized due to the actions of the Holocene dominant winds (NE) and deposited as sands dunes. The mineralogy indicates that the dominant minerals in the loess sediments of the south of Córdoba Province are light minerals such as K-feldspars, quartz, volcanic glass (up to $20 \%$ in weight) and plagioclase. Pyroxenes, amphiboles and opaque are present in decreasing order of abundance. Illite is the main clay with a subordinate amount of montmorillonite (Ortolani, 2007).

The direction of groundwater flow in the study area is northwest to southeast through the dunes area (Figure 5). The highest thickness of unsaturated zone in the study area is located in the centre of the dune area where the unsaturated zone can reach up to $8.1 \mathrm{~m}$ in thickness (P1) (Figure 3).

Hydraulic conductivities and transmisivity, based on pumping tests in Coronel Moldes, have yielded values of 0.2-1 m/day and 10-50 $\mathrm{m}^{2} /$ day respectively (Blarasín et al., 2004). Porosity ranges from 7\% to 10\% (Blarasín, 2003). Low groundwater velocity values (between 0.01 and $0.16 \mathrm{~m} /$ day) are associated with the flat relief of the zone which also makes it difficult to define an accurate watershed.

The average rainfall from 1896-2005 in Coronel Moldes was $813 \mathrm{~mm} /$ year. Up to $80 \%$ of the total yearly rainfall falls in the warm season (October-March). In the cold season (AprilSeptember) rain is lighter. According to Thornthwaite's method (Thornthwaite, 1948), the potential evapotranspiration (ET) is $725 \mathrm{~mm} /$ year. The excess of ET over rainfall is 88 $\mathrm{mm} /$ year, which occurs between October and April. Rainfall records from the last 100 years show an increasing trend and especially high values during the last 10 years (Figure 6). In 2004 the area registered considerable amounts of rainfall and very high groundwater levels.

The recharge of the Coronel Moldes aquifer from infiltration of rainfall throughout the area is very important. The percentage infiltration of the total annual rainfall, using chloride mass balance method, is $25 \%$ in the sand dunes area, and $11 \%$ in the rest of the plane. Elevations of groundwater level since July 2004 have occurred. However, recharge to the local flow occurs in the sand dune area. The depth of phreatic level in P1 increased to more than $1 \mathrm{~m}$ in six months (Figure 7). 
GOMEZ, M. L.; MARTÍNEZ, D. E. Municipal waste management and groundwater contamination processes in Córdoba Province, Argentina. Ambi-Agua, Taubaté, v. 5, n. 3, p. 28-46, 2010. (doi:10.4136/ambi-agua.152)

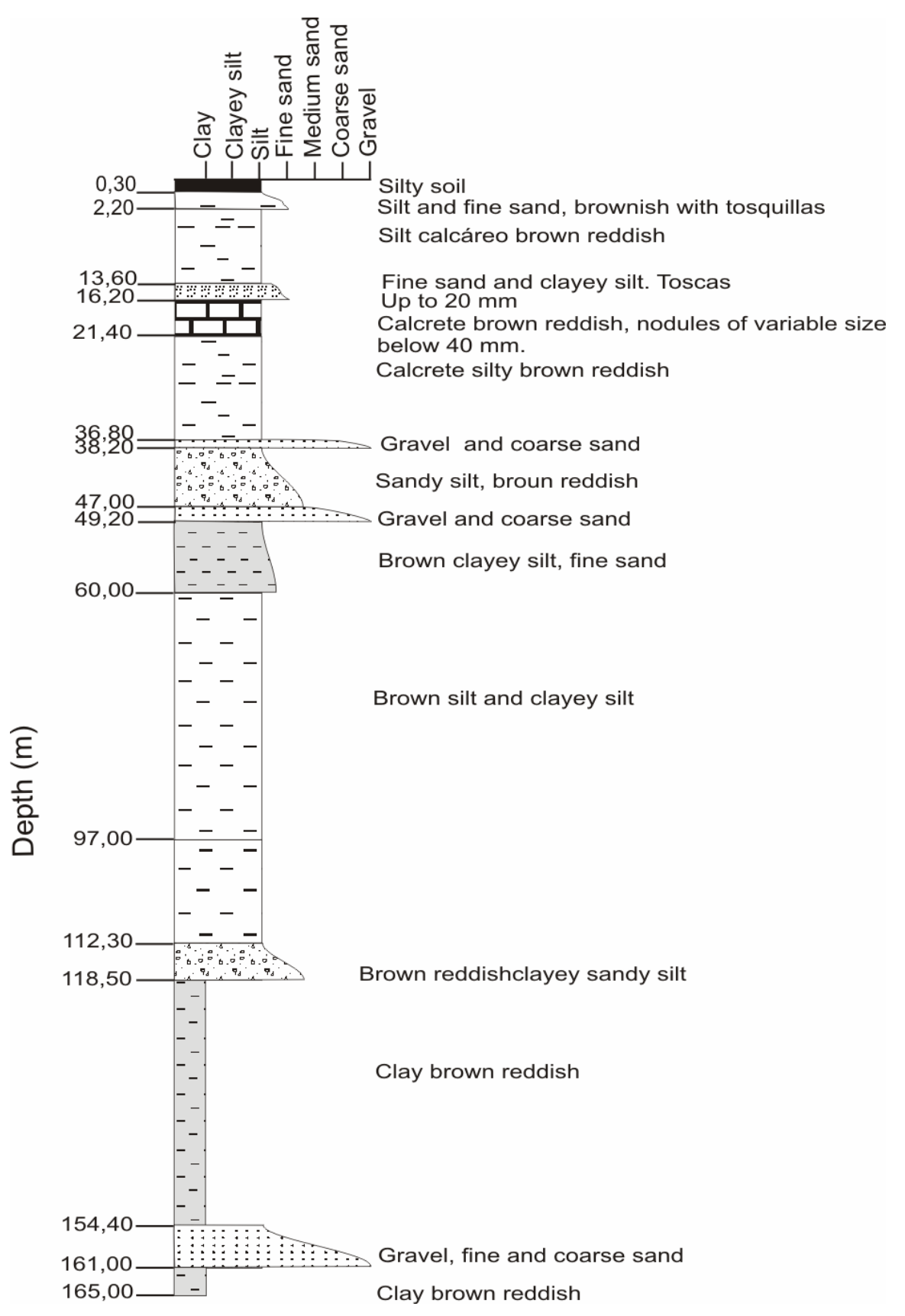

Figure 4. Lithological log of DIPAS borehole showing the sediment of

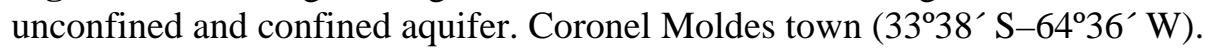



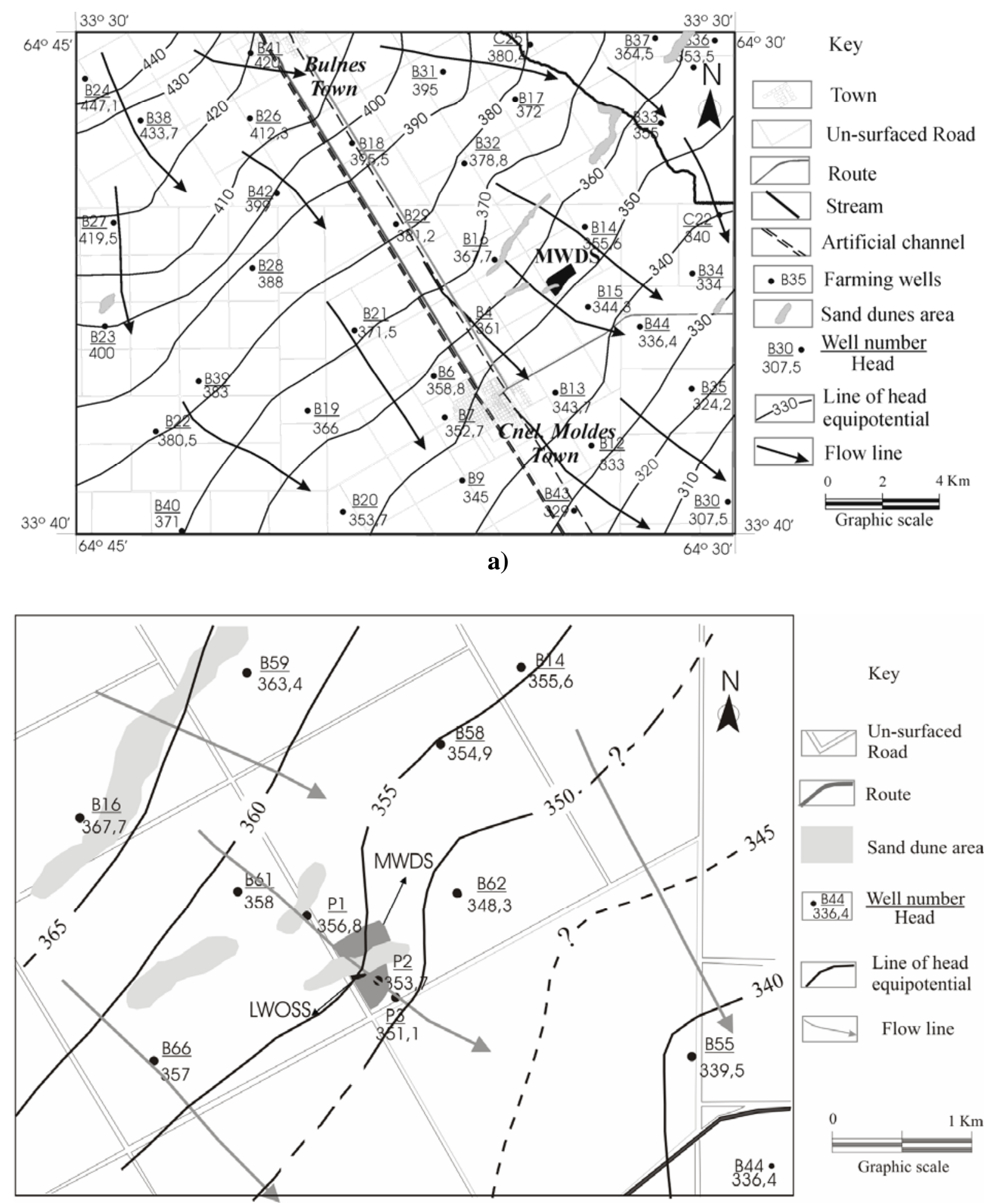

b)

Figure 5. a) Potentiometric contour map of the Coronel Moldes unconfined aquifer and, b) in MWDS area. 


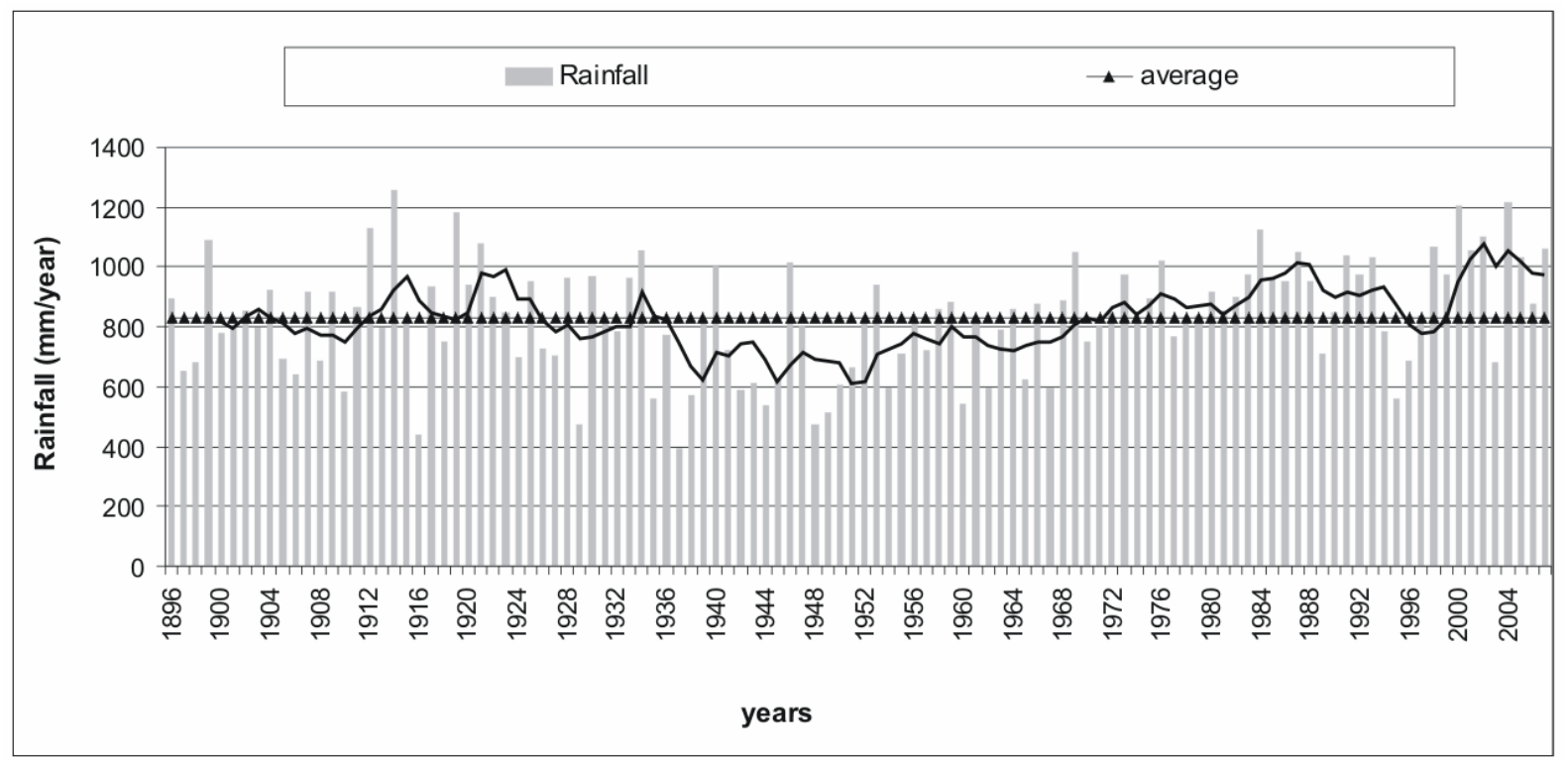

Figure 6. Rainfall in Coronel Moldes (1896-2007), $831 \mathrm{~mm} /$ years is the average in the considering internal. The black line indicates moving average each 5 years.

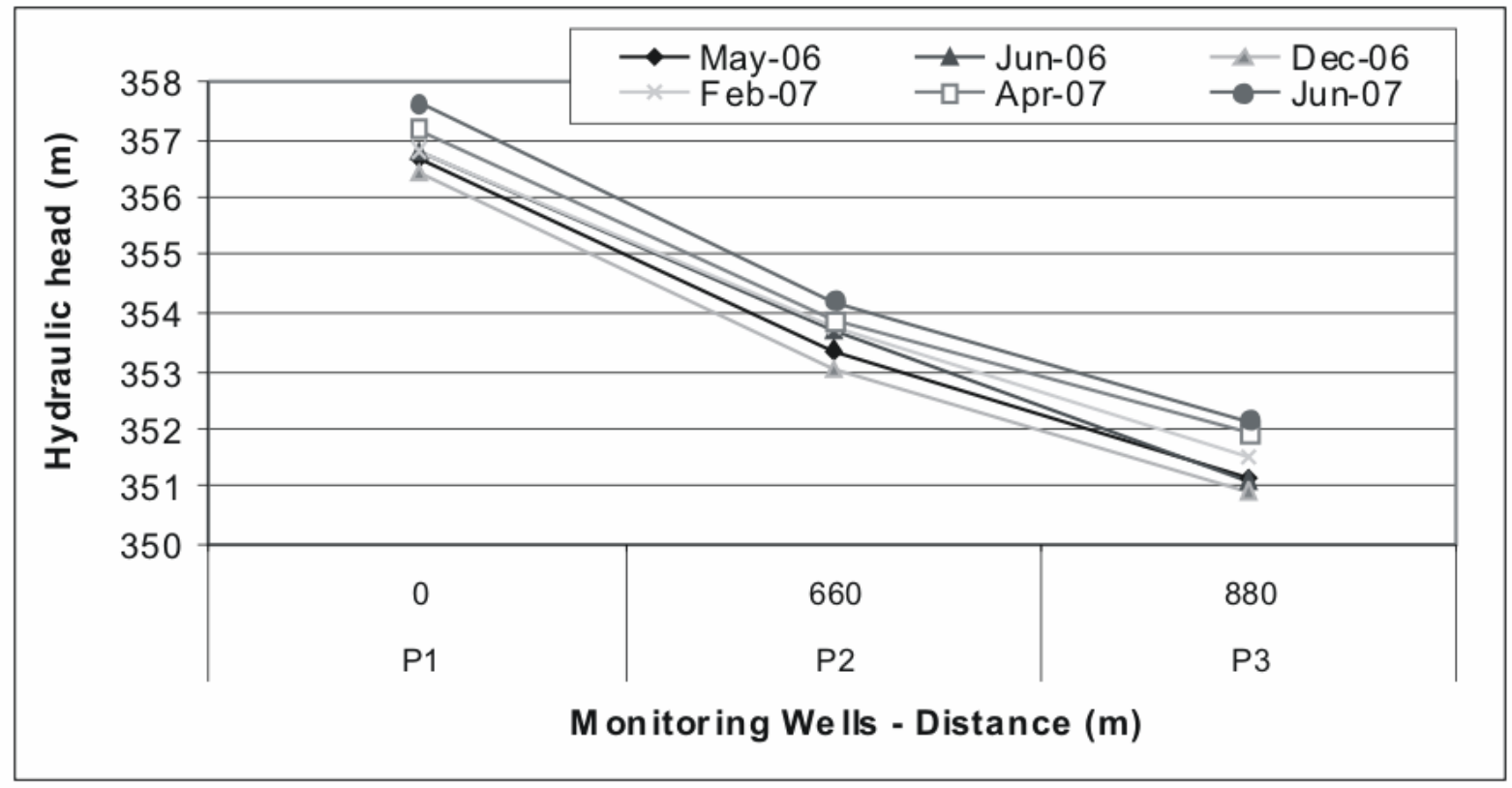

Figure 7. Hydraulic head in monitoring wells in MWDS área.

\subsection{DRASTIC vulnerability estimation}

The groundwater pollution potential of the study area was evaluated using DRASTIC (Aller et al., 1987) over an area of $440 \mathrm{Km}^{2}$. The method was used to determine aquifer vulnerability to contamination from surface sources. The acronym DRASTIC is derived from: [D] Depth to water table; [R] Recharge (net); [A] Aquifer media; [S] Soil media; [T] Topography (slope); [I] Impact of vadose zone; and [C] Conductivity (hydraulic). These parameters are the most important mapable factors which control groundwater contamination potential. The DRASTC technique involves a standardized methodology which gives results suitable for screening zones for groundwater protection, monitoring and clean-up efforts (Ahmed, 2009).

The DRASTIC Index (DI) is the weighted sum of these seven factors that might affect contaminant movement. The index is expressed as:

$\mathrm{DI}=\mathrm{DW} \mathrm{DR}+\mathrm{RW} \mathrm{RR}+\mathrm{AW} \mathrm{AR}+\mathrm{SW} \mathrm{SR}+\mathrm{TW} \mathrm{TR}+\mathrm{RW} \mathrm{RR}+\mathrm{IW} \mathrm{IR}+\mathrm{CW}$ CR 
where the subscript $\mathrm{R}$ stands for rating, and the subscript $\mathrm{W}$ stands for weight. Each DRASTIC factor is assigned a weight based on its relative significance in affecting pollution potential. The typical ratings range from 1 to 10 and the weights from 1 to 5 . The calculated DI is used to classify areas according to their susceptibility to groundwater contamination. A higher DRASTIC index indicates a greater vulnerability to contamination. The index generated provides only a relative evaluation tool and is not designed to produce absolute answers or to represent units of vulnerability (Chowdhury et al., 2003).

Table 2 and Figure 8 show the DRASTIC index results for Coronel Moldes and surrounding areas. Parameters were assigned considering results from geologicalgeomorphological and hydrogeological studies in Gomez (2009) and Gomez et al. (2009a). Results from a pumping test undertaken in Coronel Moldes as part of a study for the municipal government from Blarasín et al. (2004) were also incorporated.

Table 2. Assigned weights and ratings for DRASTIC features in the study area. Rates and ratings have been considered from Aller et al. (1987).

\begin{tabular}{|c|c|c|c|}
\hline Factor & $\begin{array}{l}\text { Importance } \\
\text { Weight (w) }\end{array}$ & Range & Rating \\
\hline Depth to groundwater & 5 & $\begin{array}{l}>\text { de } 11 \mathrm{~m} \\
11 \mathrm{~m}-5 \mathrm{~m} \\
5 \mathrm{~m}-3 \mathrm{~m} \\
<\mathrm{de} 3 \mathrm{~m}\end{array}$ & $\begin{array}{l}5 \\
7 \\
9 \\
10\end{array}$ \\
\hline Recharge rate (net) $^{*}$ & 4 & $\begin{aligned} & 91 \text { mm/year } \\
> & 200 \text { mm/year }\end{aligned}$ & $\begin{array}{l}3 \\
8\end{array}$ \\
\hline Aquifer media & 3 & Fine Sand and silt & 2 \\
\hline Soil media & 2 & Sandy loam & 4 \\
\hline Topography (slope) & 1 & $<\operatorname{del} 2 \%$ & 10 \\
\hline $\begin{array}{l}\text { Impact of the vadose } \\
\text { zone }\end{array}$ & 5 & $\begin{array}{l}\text { Fine Sand - Silt and medium-coarse sand } \\
\text { in alluvial plain in the Sampacho's stream }\end{array}$ & 2 \\
\hline $\begin{array}{l}\text { Conductivity } \\
\text { (hydraulic) of the } \\
\text { aquifer }\end{array}$ & 3 & $0,2-1 \mathrm{~m} /$ day & 1 \\
\hline
\end{tabular}

${ }^{*}$ High percentage of recharge corresponds to the sand dunes areas (Rating 8) and the lower value was calculated for the rest of the area. Source: Gomez et al. (2009b).

Depth to water table is often the most important hydrogeological characteristic in loess aquifers, since it provides a greater chance for natural attenuation (such as sorption, biodegradation, volatilization, dispersion) to occur as the depth to water increases (longer travel times). Since the depth to water table is straightforward, a maximum value of 5 was attributed to this parameter (Nobre et al., 2007). The groundwater elevation map is shown in Figure 8, showing depths to groundwater ranging from less than $3 \mathrm{~m}$ to more than $11 \mathrm{~m}$. 
Net recharge is a significant factor controlling the leaching of contaminants to the vadose and saturated zones. The area of sand dunes at the MWDS constitutes a local recharge zone where the recharge is approximately $25 \%$ of precipitation, while in the rest of the plain the recharge is less than $11 \%$ (Gomez et al., 2009b).

The attenuation capacity of the aquifer media is evaluated on the basis of grain sizes, fractures and solution opening. The soil media is evaluated on the basis of the type of clay present and the grain size of the soil. The topography refers to the slope ranges chosen as significant relative to groundwater pollution potential. The vadose zone is evaluated on the basis of grain size, fracture and solution openings and sorption potential (Aller et al., 1987). The hydraulic conductivity controls the rate of groundwater movement in the saturated zone, thereby controlling the degree and fate of the contaminants (Ahmed, 2009).

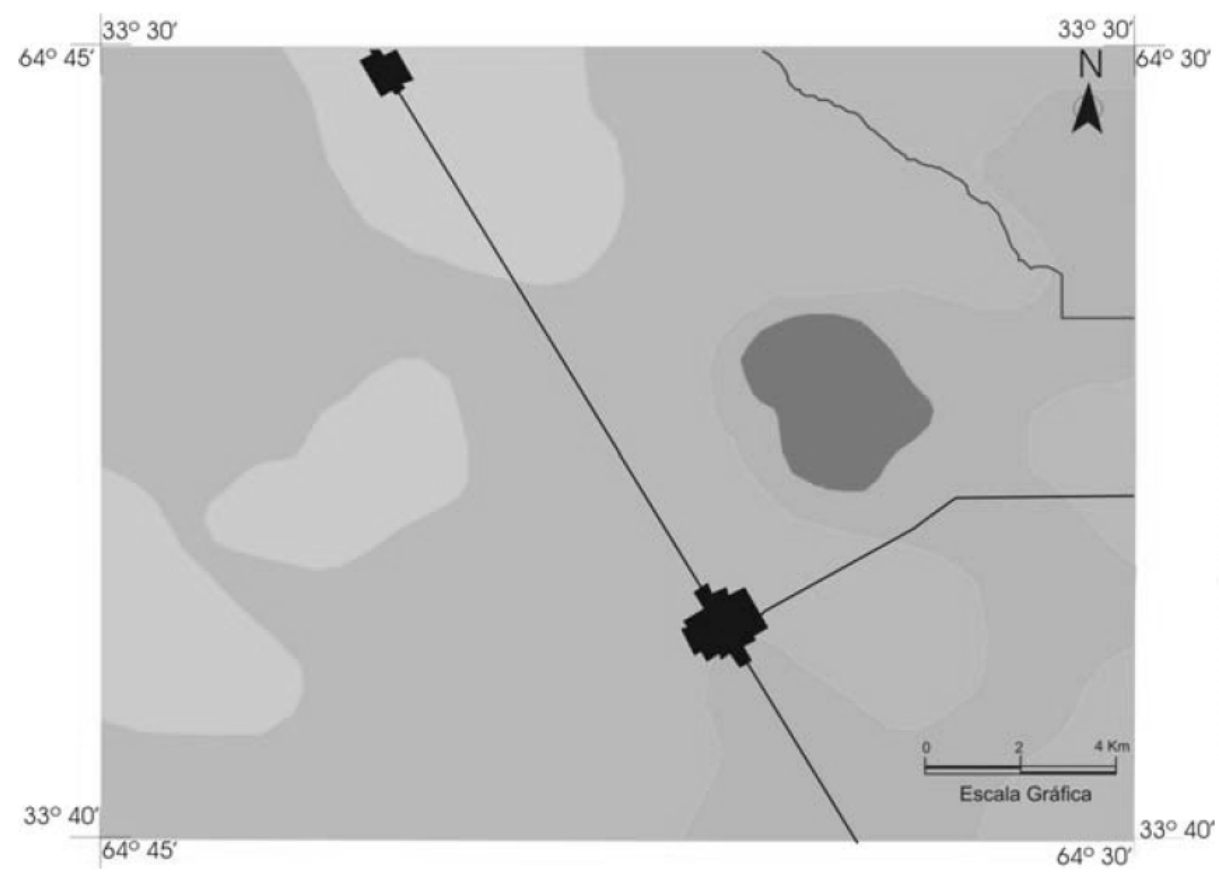

References

Population

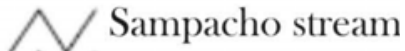

14 Route

Depth to water table

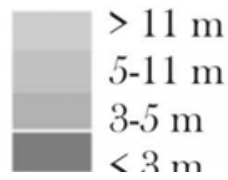

Figure 8. Index of depth to water table.

\subsection{Aquifer vulnerability in Coronel Moldes area}

Figure 9 shows two areas of the Coronel Moldes unconfined aquifer characterized by different contamination vulnerability indices. DRASTC indices result in values between 74 and 119, corresponding to two classifications - 74-93 (ModerateVulnerability) and 94-119 (High Vulnerability), the second of these two including the aquifer in the vicinity of the MWDS. This relatively small range of aquifer vulnerability can be attributed to the homogeneity of geological-geomorphological characteristics in the area. However, it should be stressed that the scale of investigation undertaken in this study does not allow representation of local scale processes in the zone of sand dunes where much greater depths to the phreatic level (near $8 \mathrm{~m}$ ) exist (Figure 3). The study indicates that the aquifer in the vicinity of the municipal waste disposal site is characterized by High Vulnerability with the rest of the area having a Moderate Vulnerability. These classifications show the high susceptibility of the groundwater system to surface contamination.

The depth to groundwater represents an important factor that accounts for the level of groundwater vulnerability in the sand dunes area where it is common to see small lakes arising from groundwater springs where depth to groundwater is less than $3 \mathrm{~m}$. Depth to groundwater determines the thickness of materials through which a contaminant must travel before reaching the aquifer and can also be used to determine the contact time with surroundings materials (Aller et al., 1987). In relation to this, the presence of dunes creates a 
local recharge area with a direct influence on the transport of contamination though the vadose zone. The sand dunes area requires special care in terms of groundwater protection because it is the only source of freshwater recharge to the unconfined aquifer which supplies much of Coronel Moldes' rural communitites. The Net Recharge factor, related to the total quantity of water that infiltrates from the ground surface to the aquifer (Aller et al., 1987), is therefore significant here (Table 2).

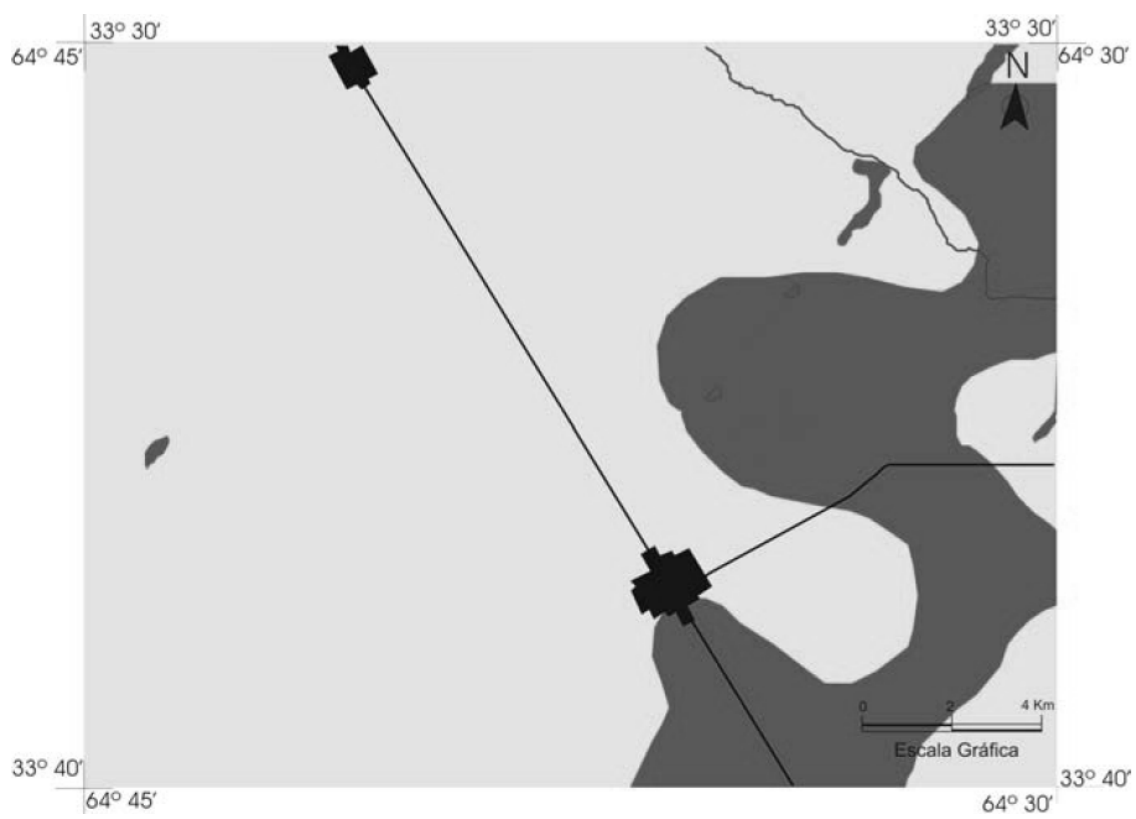

References

Population

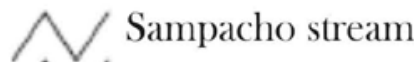
\14 Route

DRASTIC Vulnerability Index 74 - 93 (Moderate) 94 - 119 (High)

Figure 9. Intrinsic Vulnerability Index mapping of Coronel Moldes aquifer.

\subsection{Hydrogeochemistry of the Coronel Moldes aquifer}

The chemical composition of selected water samples was plotted on a Piper diagram, shown in Figure 10. The main groundwater types found in the Coronel Moldes aquifer are sodium-bicarbonate-sodium, bicarbonate-sulfide and sodium-sulfate, which are related to the aquifer's position as a transition area in the regional groundwater flow system. The statistical parameters from hydrogeochemical determinations are shown in Table 3.

Table 3. Statistical parameters of groundwater samples from 38 farming wells in Coronel Moldes aquifer. Units expresses in $\mathrm{mg} / \mathrm{l}$ and EC in $\mu \mathrm{S} / \mathrm{cm}$.

\begin{tabular}{l|rrrrr}
\hline & N & Minimum & Maximum & Medium & $\begin{array}{c}\text { Standard } \\
\text { Deviation }\end{array}$ \\
\hline $\mathrm{pH}$ & 38 & 7.31 & 8.84 & 7.96 & 0.35 \\
$\mathrm{EC}$ & 38 & 994.00 & 3130.00 & 2021.15 & 470.50 \\
$\mathrm{HCO}_{3}{ }^{-}$ & 38 & 460.00 & 912.50 & 636.80 & 113.50 \\
$\mathrm{SO}_{4}^{-2}$ & 38 & 35.40 & 601.50 & 272.55 & 165.24 \\
$\mathrm{Cl}^{-}$ & 38 & 28.60 & 368.60 & 156.47 & 80.60 \\
$\mathrm{Na}^{+}$ & 38 & 235.10 & 687.60 & 464.25 & 117.15 \\
$\mathrm{~K}^{+}$ & 38 & 5.70 & 18.00 & 10.15 & 2.51 \\
$\mathrm{Ca}^{+2}$ & 38 & 3.20 & 50.40 & 22.14 & 11.99 \\
$\mathrm{Mg}^{+2}$ & 38 & 3.90 & 62.90 & 15.38 & 10.30 \\
$\mathrm{As}_{(\text {Total }}$ & 36 & 0.00 & 0.25 & 0.07 & 0.08 \\
$\mathrm{~F}^{-}$ & 38 & 0.50 & 12.00 & 3.52 & 2.35 \\
$\mathrm{NO}_{3}{ }^{-}$ & 38 & 10.00 & 200.00 & 95.43 & 67.27 \\
\hline
\end{tabular}

The average solute concentration, electrical conductivity, is nearly 2,000 $\mu \mathrm{S} / \mathrm{cm}$. In the local recharge area the values are below $700 \mu \mathrm{S} / \mathrm{cm}$. The high concentrations of nitrate 
present are common over the whole area and indicate contamination from on-site sanitation systems and feedlots in rural areas, which cause shallow contamination by nitrogen and bacteria. The $\mathrm{pH}$ value, the presence of nitrates and the absence of nitrite indicate alkaline and oxic conditions for groundwater in the whole area.

$\mathrm{Na}^{+}$and $\mathrm{HCO}_{3}^{-}$are the dominant major ion species in groundwater. High $\mathrm{Na}^{+}$ concentrations are mainly attributed to cation exchange by Na-rich clays, which are common in this sediment (Ortolani, 2007). The total hardness of groundwater varies between 76 and $370 \mathrm{mg} / \mathrm{l}$, with a mean of $118 \mathrm{mg} / \mathrm{l}$, indicating moderately hard waters. Arsenic and fluoride are common in this unconfined aquifer and were studied by Gomez et al. (2009). Results of the measurements are shown in Table 3. Both elements are present in high concentrations and the main source of these elements is minerals in the loess sediments (Smedley et al., 2002; Gomez et al., 2009a). Values of dissolved oxygen (DO) measured in the regional aquifer is between 5-7 mg/l (Blarasín, 2003).

\subsection{Hydrogeochemistry in MWDS area}

The geochemical composition of water samples taken from the aquifer in the MWDS area is of sodium-bicarbonate type. As with the samples analyzed from the surrounding area, $\mathrm{Na}^{+}$and $\mathrm{HCO}_{3}{ }^{-}$are the dominant major ion species present. Water samples taken from P2, located just downstream of the MWDS, had a higher electrical conductivity than samples taken from P3, further downstream, which in turn had a higher conductivity than samples taken from P1, located upstream of the MWDS.(Table 4).

Table 4. Groundwater composition from the phreatic aquifer in MWDS measured in March 2007. Units expressed in $\mathrm{mg} / \mathrm{l}$ and $\mathrm{EC}$ in $\mu \mathrm{S} / \mathrm{cm}$.

\begin{tabular}{c|ccccccccccccccc}
\hline Monitoring wells & $\mathbf{p H}$ & $\mathbf{C o n d}$ & $\mathbf{C O}_{3}^{-2}$ & $\mathbf{H C O}_{3}^{-}$ & $\mathbf{S O}_{\mathbf{4}}^{-2}$ & $\mathbf{C l}^{-}$ & $\mathbf{N a}^{+}$ & $\mathbf{K}^{+}$ & $\mathbf{C a}^{+2}$ & $\mathbf{M g}^{+2}$ & $\mathbf{A s}^{-}$ & $\mathbf{F}^{-}$ & $\mathbf{N O}_{3}^{-}$ & $\mathbf{N O}_{2}^{-}$ & $\mathbf{N H}_{4}^{+}$ \\
\hline P1 & 8.17 & 650 & $\mathrm{LLD}^{*}$ & 410 & 31.1 & 8.6 & 83.9 & 3.5 & 49.6 & 19.0 & 0.005 & 1.3 & 32 & 0.0 & $\mathrm{ND}^{*}$ \\
P2 & 8.55 & 2,000 & 21 & 822.5 & 54.9 & 180.0 & 473.2 & 9.0 & 21.6 & 15.6 & 0.07 & 4.2 & 77 & 8.0 & $\mathrm{LLD}$ \\
P3 & 8.4 & 1,394 & 4 & 723.8 & 51.7 & 34.3 & 326.1 & 6.5 & 12.0 & 6.3 & 0.05 & 2.6 & 40 & 3.0 & $\mathrm{LLD}$ \\
\hline
\end{tabular}

$\mathrm{ND}^{*}$ Non detectable

LLD* less than limit detected $(0.01 \mathrm{mg} / \mathrm{l})$

The same evolution of groundwater chemistry along a flow path is observed with $\mathrm{pH}$, $\mathrm{SO}_{4}^{-2}, \mathrm{Cl}^{-}, \mathrm{NO}_{3}^{-}, \mathrm{Na}^{+}, \mathrm{HCO}_{3}^{-}$. The high concentration of $\mathrm{HCO}_{3}^{-}$under the MWDS indicates that a high content of organic matter infiltrates into the aquifer from the MWDS and LWOSS. Deutsch (1997) states that the presence of the disposal site disrupts the established geochemical equilibrium between dissolved concentrations and solid/gas-phases compositions. The geochemical evolution of groundwater under and downstream from the MWDS can be explained as follows. The rainfall entering at the MWDS is initially oxidizing because of its contact with oxygen in the atmosphere. Under these conditions, organic matter is oxidized using dissolved oxygen and producing $\mathrm{CO}_{2}$. The production of $\mathrm{CO}_{2}$ by oxidation of organic matter lowers the $\mathrm{pH}$ of the groundwater. High $\mathrm{CO}_{2}$ concentrations increase the amount of carbonic acid in solution, creating a more acidic solution. However, $\mathrm{pH}$ is highest in P2, because this acidic solution reacted with sediments in the unsaturated zone, dissolving calcretes in the formation and buffering the acidity. 


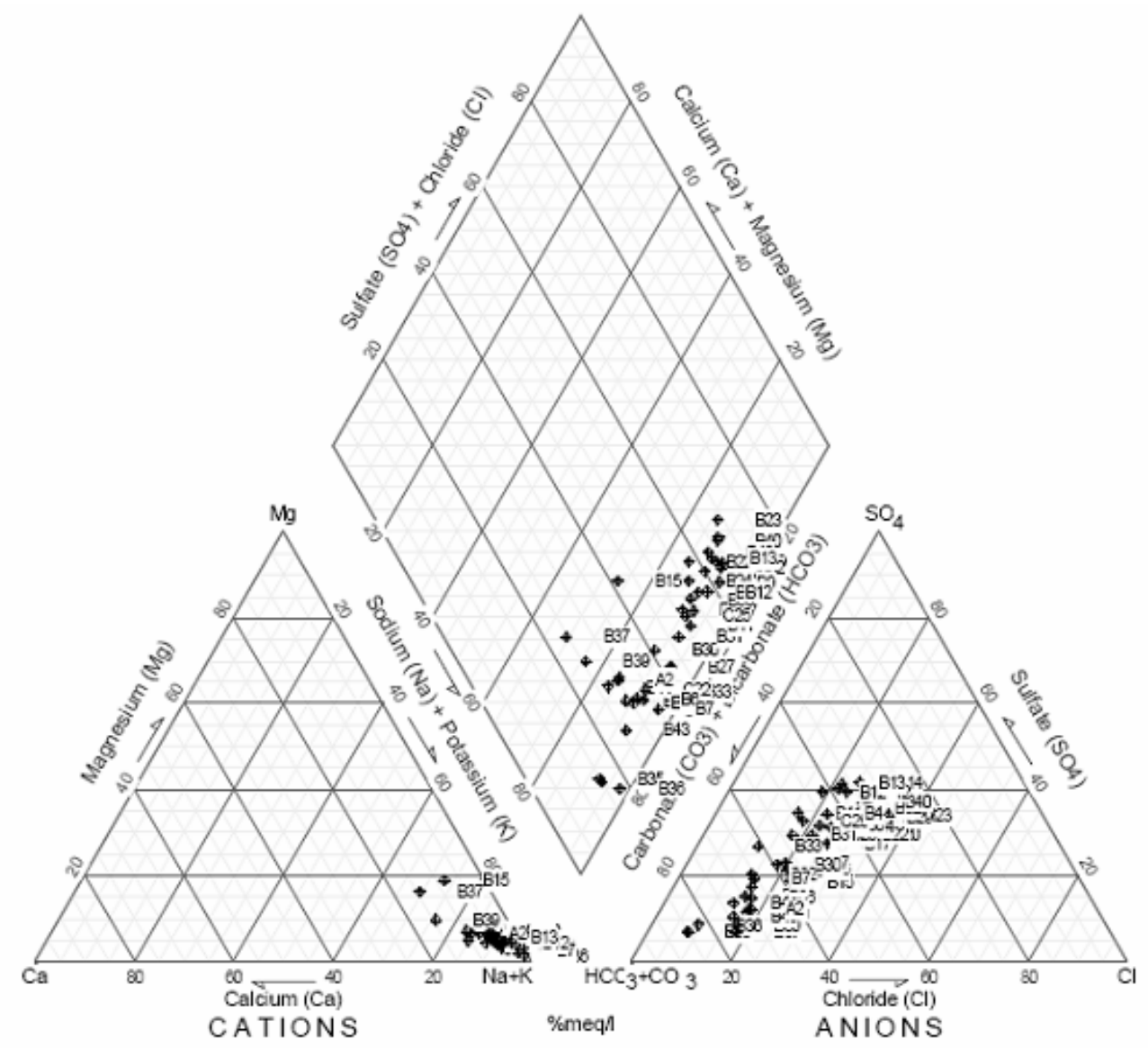

Figure 10. Piper diagram showing the chemical composition of groundwater from the Coronel Moldes aquifer.

$\mathrm{Ca}^{+2}$ is present in high concentrations at $\mathrm{P} 1$ and low concentrations at $\mathrm{P} 2$. Lower values of $\mathrm{Ca}^{+2}$ in $\mathrm{P} 2$ show slight oversaturation in $\mathrm{CaCO}_{3}$ causing a decrease of $\mathrm{Ca}^{+2}$ in solution (Figure 11). High $\mathrm{CO}_{2}$ pressures together with high $\mathrm{HCO}_{3}{ }^{-}$concentrations in the groundwater in contact with sediments (silicates and $\mathrm{CaCO}_{3}$ ) are responsible for this calcite equilibrium. However, samples taken from $\mathrm{P} 1$ have the highest values of $\mathrm{Ca}^{+2}$ and $\mathrm{Mg}^{+2}$. This is because water from the local recharge area infiltrates too rapidly to allow time for exchange of $\mathrm{Ca}^{+2}$ and $\mathrm{Na}^{+}$ions in the clay minerals present.

The total hardness of groundwater reduces from P1 to P3, with $202 \mathrm{mg} / \mathrm{l}$ in P1, $118 \mathrm{mg} / \mathrm{l}$ in P2 and the lowest value of $56 \mathrm{mg} / \mathrm{l}$ in P3 indicates a very high, moderate and slightly hard type, respectively.

Nitrites were found only in P2 and P3, and are present in low concentrations. Nitrates were measured in all samples but P1 shows lower concentrations than those in P2 and P3 (Table 3). Ammonia and nitrite are, under aerobic conditions, quickly oxidized to nitrate. In this case a weak reducing environment is created by the MWDS and LWOSS affecting the concentrations of nitrogen species in groundwater. Decomposition of organic matter in the MWDS and dissolved nitrogen species from the LWOSS produce the nitrogen species present under and downstream of the MWDS. Studies from Foster and Hirata (1988) indicate that each person can generate $4 \mathrm{~kg} /$ year of potential nitrate.

Higher values of $\mathrm{As}_{\text {(Total) }}$ and $\mathrm{F}^{-}$were found under the MWDS (P2) with respect to samples taken from P1 and P3. Environmental conditions are favorable under the MWDS for mobilization of $\mathrm{As}_{\text {(Total) }}$ and $\mathrm{F}$ from sediments. These conditions include high $\mathrm{HCO}_{3}{ }^{-}$ concentrations and alkaline $\mathrm{pH}$ increasing the dissolutions of volcanic glass from the loess sediments (Gomez et., 2009a). The leachate extends beyond the MWDS and is introduced 
into the unsaturated and saturated zones creating local conditions that can result in the release of naturally occurring arsenic and fluoride from aquifer sediments.

Values of dissolved oxygen (DO) in piezometers P2 and P3 (4.5 y $4.3 \mathrm{mg} / \mathrm{l}$ respectively) indicate the presence of organic matter in groundwater under the MWDS. The analysis of $\mathrm{BOD}_{5}$ and COD is useful to characterize effluents and polluted waters. The presence of these parameters in high concentrations is the result of organic matter and inorganic compounds that migrate from the MWDS and LWOSS into the aquifer. Accordingly, the bacteriological analyses in P2 and P3 show high values for aerobic and anaerobic bacteria, total coliforms and faecal coliforms (pseudomonas aeruginosa) (Table 5).

Table 5. COD, $\mathrm{BOD}_{5}$ and bacteriological analysis measured in groundwater in monitoring wells in the MWDS area in March 2007.

\begin{tabular}{c|cc|cc}
\hline \multicolumn{2}{|c|}{} & \multicolumn{2}{c}{ Bacteriological analysis } \\
\hline Samples & COD & BOD $_{\mathbf{5}}$ & $\begin{array}{c}\text { Coliforms organisms } \\
\text { [NMP/100ml] }\end{array}$ & $\begin{array}{c}\text { Aerobic and anaerobic } \\
\text { Microorganisms [ } \mathbf{\mu f c} / \mathbf{m l}]\end{array}$ \\
\hline P1 & 47.3 & 6.6 & 3 & 50 \\
P2 & 62.3 & 12.8 & 150 & 620 \\
P2 & 79.8 & 12.4 & $>\mathrm{a} 1,100$ & 2,300 \\
\hline
\end{tabular}

Groundwater quality is suitable for human consumption of the water in P1 only. In the rest of the monitoring wells ( $\mathrm{P} 2$ and $\mathrm{P} 3$ ), $\mathrm{As}_{\text {(Total) }}, \mathrm{F}^{-}, \mathrm{NO}_{3}{ }^{-}$and aerobic bacteria exceed the permissible limits for water supply.

Inverse geochemical modeling undertaken by Gomez et al. (2009b) indicates that groundwater in piezometer P2 is derived 43\% from the MWDS leachate and 57\% from noncontaminated groundwater. In piezometer P3, $11 \%$ of groundwater is derived from the leachate and $89 \%$ from non-contaminated groundwater.

\subsection{Gibb’s diagrams}

Gibb's diagrams were used to show the mechanisms that control groundwater chemistry in the MWDS area. The diagrams show the ratio of $\mathrm{Na}^{+}$to $\left(\mathrm{Na}^{+}+\mathrm{Ca}^{+2}\right)$ and $\mathrm{Cl}^{-}$to $\left(\mathrm{Cl}^{-}+\right.$ $\mathrm{HCO}_{3}{ }^{-}$) versus TDS, and are widely employed to assess the functional sources of dissolved chemical constituents, such as precipitation-dominance, rock-dominance and evaporationdominance (Gibbs, 1970).

Gibb’s diagrams for chemical analysis at P1 (Figure 12) suggest that weathering is the main process that influences groundwater chemistry. Diagrams for P2 and P3 suggest that natural processes are insufficient to explain groundwater chemistry. Hence, an additional source of $\mathrm{Na}^{+}$and $\mathrm{Cl}^{-}$is necessary to explain this process. The increase of salinity, $\mathrm{Na}^{+}$and $\mathrm{Cl}^{-}$concentrations in P2 and P3 demonstrate the presence of anthropogenic influences on groundwater quality under the MWDS and LWOSS. 


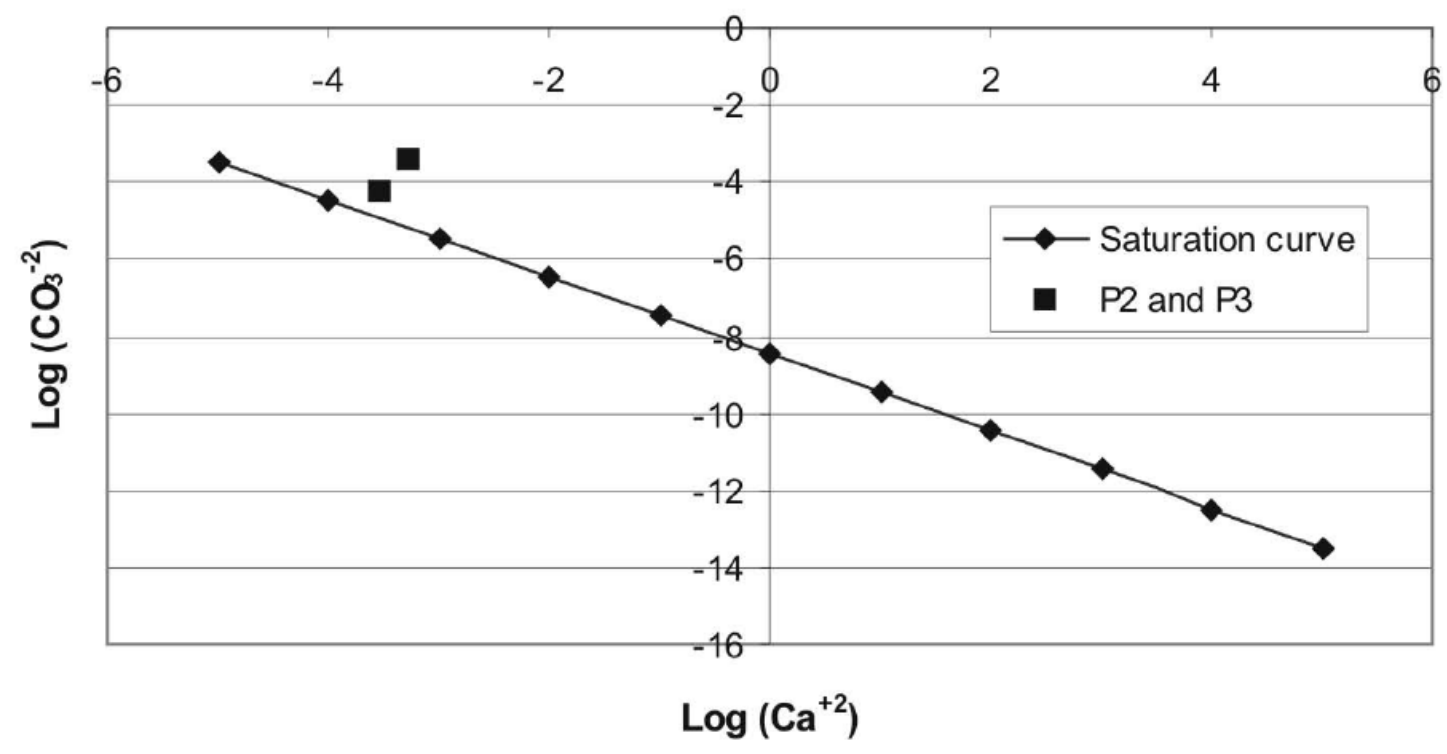

Figure 11. The stability of calcite and the saturation of groundwater in the MWDS area.

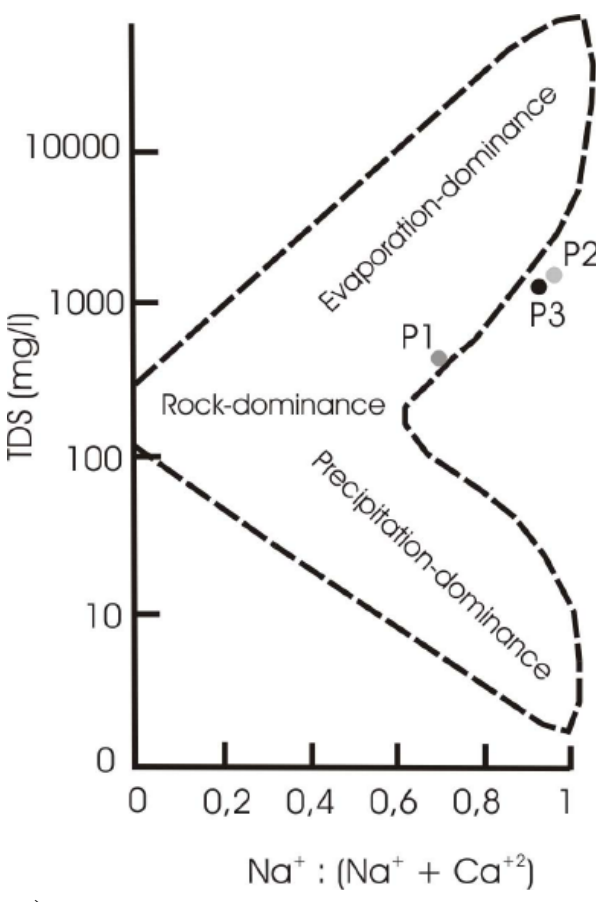

a)

Figure 12. Mechanisms controlling groundwater quality from the phreatic aquifer in the MWDS area. a) $\mathrm{Na}^{+} / \mathrm{Na}^{+}+\mathrm{Ca}^{+2}$ (mg/l) versus TDS (mg/l). b) $\mathrm{Cl}^{-} / \mathrm{Cl}^{-}+\mathrm{HCO}_{3}^{-}$versus TDS (mg/l).

\section{CONCLUSIONS}

Uncontrolled municipal waste disposal sites need to be more adequately managed in order to allow sustainable environmental management in the Coronel Moldes area. The determination of the Groundwater Vulnerability in this study was very simplified and elementary. However, the results are consistent and show that groundwater in the study area 
has a high vulnerability to contamination, resulting in groundwater contamination in the vicinity of a municipal waste disposal site (MWDS).

The MWDS and liquid waste from on-site sanitation (LWOSS) contaminate the local groundwater. High concentrations of $\mathrm{Na}^{+}, \mathrm{SO}_{4}{ }^{-2}, \mathrm{Cl}^{-}$and $\mathrm{HCO}_{3}{ }^{-}$were found in groundwater under the MWDS. Groundwater along a flow path through the MWDSS indicates a decrease in dissolved oxygen concentrations and an increase in organic compounds (presence of bacteria and high $\mathrm{BOD}_{5}$ ) downstream of the facility. This study did not estimate the significance of $\mathrm{CH}_{4}$ emissions from anaerobic biodegradation of municipal wastewater.

The Coronel Moldes MWDS is a small and relatively new disposal site where the oxygen available is enough to oxidize reactive organic matter. Part of this organic matter, mainly supplied by the LWOSS, percolates through the disposal site and enters into the unsaturated zone lowering dissolved oxygen concentrations and reducing oxidized species like nitrate.

As Zaporozec (2002) and other authors indicate, the leachate coming from the municipal solid waste usually contains inorganic components including chlorides, sulfates, carbonates, nitrogen compounds and a wide range of organic compounds. All of these compounds were found in the groundwater under the disposal site in samples taken from P2. The concentrations of these indicators decreased consistently downstream to P3. Analyses have shown the influence of the disposal site on the groundwater and the tendency to reduce back to values more typical of the regional aquifer by around $30 \mathrm{~m}$ down gradient the municipal waste disposal site.

The organic load from the MWDS appears to be quite high. Bacteriological analysis, low ratios of $\mathrm{BOD}_{5}$ to $\mathrm{COD}$, low ammonium and low DO demonstrated the presence of organic matter in groundwater under and near MWDS and LWOSS. The inverse modeling mixing ratios on groundwater with oxygen and nitrogen isotopes could be checked in further studies. This information would allow for the identification of different sources of groundwater contaminants.

It is common that the treatment of municipal solid wastes in small towns ( $<$ than 20.000 inhabitants) in developing countries lacks control from the government. Liquid wastes from on-site-sanitation systems are often a problem where untreated leachate is allowed to infiltrate directly into the unsaturated and saturated zones. In Coronel Moldes, it was necessary to establish the state of groundwater and to determine how these contaminant sources affect groundwater.

Considering that the polluting load can be controlled or modified, but that the vulnerability of the aquifer cannot, this study demonstrates the necessity for adaptive measures to be taken to reduce the risk of contamination to the aquifer. This is especially important in a zone where groundwater is the only available resource for all the uses.

This paper suggests that current waste disposal practices are not adequate to ensure the sustainable development of Coronel Moldes. In order to stop contamination of a local recharge zone with a High Vulnerability index, it is necessary to exchange the waste disposal systems currently in use, such as septic tanks and cesspools, for a better managed sewage system. In addition, the requirement for engineered and well managed landfills, as a necessary component of any municipal solid waste management system is clear. It is the responsibility of local authorities to develop a prevention program that locates the MWDS as far away as possible from zones of high aquifer vulnerability and to design these facilities to prevent groundwater contamination. Waste recycling, incineration and composting can reduce the quantity of materials sent to a landfill, but there will always be residual materials that require landfilling (Rhyner et al., 1995; EPA, 1999). A new management system for municipal solid and liquid wastes at Coronel Moldes is recommended. This management system should include for the provision of alternative sanitary landfills that satisfy environmental criteria. Furthermore, strict supervision of liquid municipal waste management, including the 
introduction of a sewer system in place of cesspools and septic tanks, is necessary to ensure groundwater protection and sustainable environmental management.

Many cities in Latin-America are small cities like Cnel. Moldes. The findings of this survey indicate that still in small cities the inadequate management of leachate results in damaging the groundwater quality, mainly in highly vulnerable aquifers. If well the extension of reducing conditions can be detected just few meters downgradient, the effect in conservative pollutants can affect larger aquifer areas.

\section{ACKNOWLEDGEMENTS}

Financial support for this project came from SECyT (Secretaría de Ciencia y Técnica) from Universidad Nacional de Río Cuarto. The National Council of Scientific and Technological research (CONICET) provided a grant for PhD studies to M.L. Gomez, in which course the data for this article were obtained. We are thankful to James Bellin and Vanesa Ghigi for there help correcting the English language.

\section{BIBLIOGRAPHY}

AHMED, A. Using generic and pesticide DRASTIC GIS-based models for vulnerability assessment of the Quaternary aquifer at Sohag, Egypt. Hydrogeology Journal, v. 17, n. 5. p. 1203-1217.

ALlER, L.; Bennett, T.; Lehr, J. H.; Petty, R.; Hackett, G. DRASTIC: a standardized system for evaluating ground water potential using hydrogeologic settings. Ada: USEPA, 1987. 622 p. Rep. 600/287/035.

AMERICAN PUBLIC HEALTH ASSOCIATION - APHA; AMERICAN WATER WORKS ASSOCIATION - AWWA;WATER POLLUTION CONTROL FEDERATION WPCF. Standard methods for the examination of water and wastewater. 17 . ed. Washington, DC: APHA, AWWA, WPCF, 1995.

BLARASÍN, M. Geohidrología ambiental del Sur de Córdoba, con énfasis en la ciudad de Río Cuarto y su entorno rural. 2003. 200f. Tesis (Doctoral) - Universidad Nacional de Rio Cuarto, Rio Cuarto, 2003.

BLARASÍN, M.; Cabrera, A.; Matteoda, E.; Gomez, M. L. Estudio hidrogeológico para el diagnóstico y propuesta de solución del problema ocasionado por el ascenso del nivel freático en la ciudad de Coronel Moldes, Córdoba. Informe técnico. Municipio de Coronel Moldes: [S.n.], 2004. 20 p.

BOCANEGRA, E.; MASSONE, H.; MARTÍNEZ, D.; CIVIL, E.; FARENGA, M. Groundwater contamination: risk management and assessment for landfills in Mar del Plata, Argentina. Environmental Geology, v. 40, n. 6, p. 742-741, 2001.

CANTÚ, M.; DEGIOVANNI, S. Génesis de los sistemas lagunazas del centro-sur de la provincia de Córdoba. In: CONGRESO GEOLÓGICO ARGENTINO, 10., 1987, Tucumán. Actas... Tucumán: AGA, 1987. 4 p.

CHOWDHURY, S.; IQBAL, M.; SZABO, J. Comprehensive approach of groundwater resource evaluation: a case study in the Chippewa Creek Watershed in Ohio. OHIO J SCI, v. 103, n. 5, p.134-l42, 2003.

DEUTSCH, W. Groundwater geochemistry: fundamentals and applications to contamination. Boca Raton: Lewis Publishers, 1997. 
DIRECCIÓN PROVINCIAL DE AGUAS Y SANEAMIENTO - DIPAS (Córdoba). Normas de calidad de aguas. Córdoba: DIPAS, 1999. 85 p.

US ENVIRONMENTAL PROTECTION AGENCY - EPA. Biosolids generation, use, and disposal in the United States. Washington, DC: EPAgency, 1999.

ENVIRONMENTAL SYSTEMS RESEARCH INSTITUTE INC. - ESRI. ARCVIEW GIS v.3.2. Washington, DC: ESRI, 1999.

FOSTER, S.; HIRATA, R. Determinación del riesgo de contaminación de aguas subterráneas. Manual del CEPIS. OPS Y OMS. Lima: OMS 200 p.

GIBBS, R. Mechanisms controlling world water chemistry. Science, v. 17, p1088-1090, 1970.

GOMEZ, M. L. Modelado geoquímico de contaminantes procedentes de efluentes urbanos e industriales en el acuífero clástico del área de Coronel Moldes, Córdoba. 2009. 290f. Tesis (Doctoral) - Universidad Nacional de Río Cuarto, Río Cuarto, 2009.

GOMEZ, M. L.; BLARASÍN, M.;MARTÍNEZ, D. Arsenic and fluoride in a loess aquifer in the central area of Argentine. Environmental Geology, v. 57, p. 143-155, 2009a.

GOMEZ, M. L.; MORIENA, R.; FELIZZIA, J.; SCHIAVO, H. Caracterización hidrogeoquímica e identificación de procesos de mezcla en un acuífero afectado por un vertedero municipal no controlado. Boletín de la Asociación Geológica Mexicana, v. 6, n. 3, p. 437-450, 2009b.

HENRY, R.; YONGSHENG, Z.; JUN, D. Municipal solid waste management challenges in developing countries - Kenyan case study. Waste Management, v. 26, p. 92-100, 2006.

NIRICH, S. Diagnóstico provincial de los sistemas de gestión de residuos sólidos urbanos. Gobierno de la provincia de Córdoba. Córdoba: Agencia Córdoba Ambiente, 2000. 70 p.

NOBRE, R; ROTUNNO FILHO, O.; MANSUR, W.; NOBRE, M.; COSENZA, C. Groundwater vulnerability and risk mapping using GIS, modeling and a fuzzy logic tool. Journal of Contaminant Hydrology, v. 94, n. 3/4, p. 277-292, 2007.

ORTOLANI, C. Estratigrafía del cuaternario del tamo medio del arroyo Achiras del Gato, Dpto Río Cuarto, Córdoba. 2007. 94f. Trabajo Final (Licenciatura) Universidad Nacional de Río Cuarto, Río Cuarto, 2007.

RHYNER, C. R.; SCHWARTZ, L. J.; WENGER, R. B.; KOHRELL, M. G. Waste management and resource recovery. Boca Raton: Lewis Publisher, 1995.

SMEDLEY, P.; NICOLLI, H.; MacDONALD, D.; BARROS, A. TULliO, J. Hydrogeochemistry of arsenic and other inorganic constituents in groundwaters from La Pampa, Argentina. Applied Geochemistry, n. 17, p. 259-284, 2002.

THORNTHWAITE, A. An approach towards a rational classification of climate. Geographic Review, v. 38, n. 1, p. 221-229, 1948.

ZAPOROZEC, A. Groundwater contamination inventory: methotological guide. UNESCO, 2002. p. 160. (IHP-VI, Series On Groundwater, 2). 